\title{
Inventory and Analysis of Phytodiversity along an Altitudinal Gradient in the Southern Slope of the Mount of Tessala (Western Algeria)
}

\author{
Houria Ouici*, Zoheir Mehdadi, Kouider Cherifi \\ Laboratory of Plant Biodiversity, Conservation and Valorization, Faculty of Natural Sciences and Life, \\ University of Djillali Liabes, Sidi Bel Abbes, Algeria \\ Email: "houhou_1982@outlook.com
}

Received 13 September 2015; accepted 22 November 2015; published 25 November 2015

Copyright (C) 2015 by authors and Scientific Research Publishing Inc.

This work is licensed under the Creative Commons Attribution International License (CC BY). http://creativecommons.org/licenses/by/4.0/

(c) (i) Open Access

\begin{abstract}
Our work consists in inventorying and analyzing the phytodiversity along an altitudinal gradient of the southern slope of the mount of Tessala (north-western Algeria). For this purpose, we choose seven stations, inside each one of them floristic statements are realized. The inventory carries out on the whole of the stations made it possible to draw up a floristic list represented by 103 species, distributed on 39 botanical families dominated by Asteraceae, Poaceae, Lamiaceae and Brasicasseae. The biological spectrum of these species reveals the predominance of the hemicryptophytes and the therophytes, and on the physiognomical level, the vegetation of our stations allows distinguishing from the tree, shrubby, bushy and herbaceous formations. The processing data obtained by the factorial analysis of correspondences (AFC) and by ascending hierarchical classification (CHA) emphasize the existence of two groups of stations. A first group of stations are located in altitude, less degraded, more diversified and where in particular the phanerophyts dominate. A second group of stations are located in low altitude, little diversified and where the degradation of vegetable cover is important, resulting in the installation of the hemicryptophyts and the therophyts.
\end{abstract}

\section{Keywords}

Mount of Tessala, Phytodiversity, Floristic Inventory, AFC, CHA

\section{Introduction}

The Mediterranean pelvis is very diverse in plant species and is of great interest to any scientific study. Its

${ }^{*}$ Corresponding author.

How to cite this paper: Ouici, H., Mehdadi, Z. and Cherifi, K. (2015) Inventory and Analysis of Phytodiversity along an Altitudinal Gradient in the Southern Slope of the Mount of Tessala (Western Algeria). Open Journal of Ecology, 5, 552-562. 
great riches of flora are related to the heterogeneity of paleogeographic factors, geological and ecological one [1].

Works on the Mediterranean formations affirm the intense decline of this species diversity [2]. Disruptions which cause this regression are complex and difficult to quantify on the phytosociological and geobotanical plane [3].

The mount of Tessala, our site of study, is located in the north-west of Algeria; it is a space which combines climatic, geographical and lithological factors. The distribution of different plant communities in this mountain remains unknown until today despite some work done by [4]-[6]. These formations are represented by a set of species of particular interest but which remain subject to ongoing uncontrolled anthropozoogenic pressures that represent a direct threat to the renewal of biological resources as well as to the balance of our study area, which the current situation is alarming. This finding is demonstrated in the work of Cherifi et al. (2011) [7] that has highlighted the decline in vegetation cover.

\section{Materials and Methods}

\subsection{Presentation of the Study Area and Station Selection}

Our study area is the southern slope of Mount Tessala part of the Tell Atlas. This mountain, who's its highest point is $1061 \mathrm{~m}$ [8], is located north of the province of Sidi Bel Abbes (Algeria north-west). The climate that prevails is Mediterranean, semi-arid to cool winter [9]. The floristic inventory is performed on seven stations selected as an altitudinal gradient on the southern slope of Mount Tessala, the choice of these stations is based on the homogeneity of the plant cover (according to the abundance and dominance of plant species). The characteristics of these stations are shown in Table 1.

\subsection{Inventory of Vegetation and Soil Analysis}

The vegetation inventory is performed by adopting the method stigmatiste Braun-Blanquet [10]. At each site, five floristic surveys area of $100 \mathrm{~m}^{2}$ each, are established during the period of maximum vegetation, ranging from March to May 2012. The floristic lists are compiled based on the following layers: tree, shrub and herbaceous. Each species is identified by a coefficient of abundance-dominance and sociability.

For each survey, we found the following stationnels characters: altitude, slope, exposure, substrate type and the rate of recovery of vegetation. The determination of species recorded is made in the laboratory using flora Quézel \& Santa [11]. The species recorded are divided into families and biological, morphological and biogeographical corresponding type.

The specific diversity of the plants studied was evaluated by the diversity index of Shannon-Wiener) [12] and Index equitability: [13]. At each station, the physico-chemical analyzes were carried out on three soil samples collected at the surface horizon of $15 \mathrm{~cm}$ of each statement, whose properties are often linked to human disturbance, agricultural or pastoral [14]. These tests consist in determining the texture, moisture, electrical conductivity, $\mathrm{pH}$, the rate of limestone and the rate of organic matter. The values for the different physical-chemical parameters are average values station.

—index of Shannon-Wiener

\begin{tabular}{ccccc}
\multicolumn{4}{l}{ Table 1. Characteristics of the sampled stations. } \\
\hline Station & Latitude Nord & Longitude & Altitude & Exposition \\
\hline St 1 & $35^{\circ} 26^{\prime} 48.1^{\prime \prime}$ & $0^{\circ} 76^{\prime} 79.2^{\prime \prime}$ & $732 \mathrm{~m}$ & South East \\
St 2 & $35^{\circ} 26^{\prime} 72.9^{\prime \prime}$ & $0^{\circ} 76^{\prime} 99.6^{\prime \prime}$ & $789 \mathrm{~m}$ & South West \\
St 3 & $35^{\circ} 27^{\prime} 13.8^{\prime \prime}$ & $0^{\circ} 77^{\prime} 42.0^{\prime \prime}$ & $828 \mathrm{~m}$ & South East \\
St 4 & $35^{\circ} 26^{\prime} 85.2^{\prime \prime}$ & $0^{\circ} 77^{\prime} 79.1^{\prime \prime}$ & $875 \mathrm{~m}$ & South East \\
St 5 & $35^{\circ} 27^{\prime} 23.7^{\prime \prime}$ & $0^{\circ} 78^{\prime} 69.9^{\prime \prime}$ & $925 \mathrm{~m}$ & South West \\
St 6 & $35^{\circ} 27^{\prime} 58.4^{\prime \prime}$ & $0^{\circ} 77^{\prime} 42.1^{\prime \prime}$ & $990 \mathrm{~m}$ & South West \\
St 7 & $35^{\circ} 27^{\prime} 63.6^{\prime \prime}$ & $0^{\circ} 77^{\prime} 36.3^{\prime \prime}$ & $1015 \mathrm{~m}$ & South East \\
\hline
\end{tabular}


$\mathrm{H}=-\sum(\mathrm{Ni} / \mathrm{N}) \times \log 2(\mathrm{Ni} / \mathrm{N})$

Or:

$\mathrm{Ni}$ : number of individuals of a given species

$\mathrm{N}$ : total number of individuals.

-Index of equitability:

Measuring the evenness is achieved in the following ratio:

$\mathrm{H}=\mathrm{H}^{\prime} / \mathrm{S} \log 2$

$\mathrm{H}^{\prime}$ : Shannon index (diversity index). S: Total number of species (species richness)

\section{Statistical Analysis}

The plant and soil data were statistically processed by the correspondence analysis (AFC) [15]. This analysis treats the soil variables together and all biological variables (plant life forms), the recovery rate of vegetation, elevation, slope, number of species and the number of families of the seven study sites.

To perform this analysis, the floristic surveys of each station were placed on an Excel spreadsheet with all the biological variables and all the variables in soil columns and lines and stations forming a matrix on which the calculations are applied using the Statistica 6.0 software.

The data obtained have been also a hierarchical cluster analysis (HCA) to better individualize the boundaries between the different stations [16]. Furthermore, comparing the similarity of the floristic composition of the stations is carried out by the similarity coefficient of SORENSEN [17]. Similarity matrices are the basis of classification and ordination of floristic tables. Only binary data of presence-absence of species were included in this analysis. The comparison between stations here rests on the use of similarity coefficient which allows assessing the degree of similarity of species lists different stations taken in pairs.

The mean values of the different physico-chemical parameters of the soil samples analyzed and the number of species and botanical families are identified by comparison of the test of variance analysis (ANOVA) and Tukey's test using the software Minitab 16.

\section{Results}

\subsection{Analysis of the Vegetation}

Analysis of different floristic surveys on all the stations highlighted certain characteristics related to inventoried species, namely the systematic diversity, biological, morphological and biogeographical spectra.

103 plant species are listed, spread over 39 different taxonomic families (Table 2). The Asteraceae family is the most represented with 15 species, with a rate of $14.56 \%$. Poaceae and Lamiaceae are second with eight species, with a rate $7.77 \%$, followed in third place by Brassicaceae species with 7, with a rate of $6.80 \%$. Other families are very poorly represented. This variability in the distribution of the families is checked by analysis of variance $(P>0.05)$.

The biological spectrum of species inventoried (Figure 1) shows the predominance of hemicryptophyts (34.95\%), followed by therophyts (33.98\%). Third, to place the chamaephyts with a rate of $12.62 \%$ followed by phanerophyts with a rate of 10.68 .

The morphological spectrum indicates the predominance of herbaceous plants (87 species or $84.46 \%$ ) of the timber (16 species, 15.5\%). Among the herbaceous annual predominate (47 species or $45.63 \%$ ) on perennial (40 species or 38.83\%). Among the woody, bushy species are best represented (8 species or $7.76 \%$ ), followed by trees (5 species or $4.85 \%$ ), shrubs (3 species or 2.92\%) (Figure 2).

Biogeographically, the Mediterranean element (35.92\%) represents almost all the settlements that characterize the sampled stations. In the second position occurs with a Eurasian element rate of $6.79 \%$. Other biogeographic types are less represented.

Of the seven selected stations, the stations S3, S4 and S5 are rich in taxa with respectively 61, 37 and 34 species compared to stations S1, S2, S6 and S7, the number of species varies between 24 and 29 species $(P>0.05)$. This indicates heterogeneity in the distribution of the vegetation of the site explored.

Diversity indices of Shannon evaluated on seven stations are variable, ranging from 1.09 to 1.95 bits/individual. This variation is related to the number of species.

The fairness index (E) is relatively high at the stations S1 (0.13) S4 (0.17), S5 (0.14), S6 (0.22) and S7 (0.20) 
Table 2. Distribution of species per family.

\begin{tabular}{|c|c|c|c|}
\hline Family & Species & $\begin{array}{l}\text { Number of } \\
\text { Species }\end{array}$ & $\begin{array}{l}\text { Rate of } \\
\text { Presence (\%) }\end{array}$ \\
\hline Apiaceae & Daucus carota L., Ammi visnaga L., Lamk, Daucus sp., Elaeoselinum sp., Torilis nodosa L. & 5 & 4.85 \\
\hline Anacardiaceae & Pistacia lentiscus L., Dactylis glomerata L., Pistacia atlantica Desf. & 3 & 2.91 \\
\hline Aspohodelaceae & Asphodelus microcarpus Salzm. et Viv. & 1 & 0.97 \\
\hline Arecaceae & Chamaerops humilis L. & 1 & 0.97 \\
\hline Araliaceae & Hedera helix L. ssp. & 1 & 0,97 \\
\hline Asteraceae & $\begin{array}{l}\text { Calendula arvensis L., Silybum marianum L., Pallenis spinosa (L.) Cass, Scolymus hispanicus L., } \\
\text { Carduus pycnocephalus L., Anacyclus clavatus (Desf.), Bellis annua L., Artemisia vulgaris L., } \\
\text { Centaurea pullata L., Centaurea eriophora L., Crepis sp., Asteriscus maritimus (L.) Less, } \\
\text { Phagnalon saxatil, Onobrychis aregentea, Anacyclus pyrethrum }\end{array}$ & 15 & 14.56 \\
\hline Brassicaceae & $\begin{array}{l}\text { Lobularia maritima (L.) Desv, Sisymbrium officinale L., Eruca vesicaria (L.) Car, Raphanus } \\
\text { raphanistrum L., Diplotaxis sp., Sinapis arvensis L., Brassica alba. }\end{array}$ & 7 & 6.80 \\
\hline Campanulaceae & Campanula sp. & 1 & 0.97 \\
\hline Caryophylaceae & Silene colorata Poiret, Dianthus serrulatus & 2 & 1.94 \\
\hline Convolvulaceae & Convolvulus althaeoides L. & 1 & 0.97 \\
\hline Cistaceae & Helianthemum appeninum (L.) Mill, Cistus albidus L., Helianthemum sp. & 3 & 2.91 \\
\hline Cupressaceae & Cupressus sempervirens. & 1 & 0.97 \\
\hline Cucurbitaceae & Bryonia dioica. & 1 & 0.97 \\
\hline Dipsacaceae & Scabiosa stellata L. & 1 & 0.97 \\
\hline Fabaceae & $\begin{array}{l}\text { Ceratonia siliqua L., Trifolium stellatum L., Trifolium angustifolium L., Calycotome intermedia, } \\
\text { Calycotome spinosa (L.) }\end{array}$ & 5 & 4.85 \\
\hline Fagaceae & Quercus ilex L. & 1 & 0.97 \\
\hline Gentianaceae & Erytheae sp., Blackstonia perfoliata L. ssp. eu-perfoliata M. & 3 & 2.91 \\
\hline Geraniaceae & Erodium moschatum (Burm.), Erodium malcoides L. Willd. & 2 & 1.94 \\
\hline Illecebraceae & Paronychia argentea (Pourr.) Lamk. & 2 & 1.94 \\
\hline Iridaceae & Iris sp. & 1 & 0.97 \\
\hline Lamiaceae & $\begin{array}{l}\text { Ballota hirsuta Benth, Thymus ciliatus Desf, Marrubium vulgare L., Salvia argentea L. ssp., Teu- } \\
\text { crium polium L., Stachys ocymastrum L. Briq, Ajuga iva L. Schreber }\end{array}$ & 8 & 7.77 \\
\hline Liliaceae & Asparagus acutifolius L., Urginea maritima L., Ornithogalum umbellatum L. & 3 & 2.91 \\
\hline Linaceae & Linum sp. & 1 & 0.97 \\
\hline Malvaceae & Malva sylvestris L. & 1 & 0.97 \\
\hline Myrtaceae & Eucalyptus globulus L. & 1 & 0.97 \\
\hline Oleaceae & Olea europaea L., Fraxinus excelsior L. & 2 & 1.94 \\
\hline Papaveraceae & Papaver hybridum L., Papaver rhoeas L. & 2 & 1.94 \\
\hline Pinaceae & Pinus halepensis L. & 1 & 0.97 \\
\hline Plantaginaceae & Plantago albicans L., Plantago lagopus L. & 2 & 1.94 \\
\hline Poaceae & $\begin{array}{l}\text { Hordeum maritimum Witth, Lagurus ovatus L., Stipa tenacissima L., Ampelodesma mauritanicum } \\
\text { (Poiret) Dur. et Sch, Dactylis glomerata L., Hordeum vulgare L., Hordeum murinum L., Bromus } \\
\text { rubens L. }\end{array}$ & 8 & 7.77 \\
\hline Polygonaceae & Rumex bucephalophorus L. & 1 & 0.97 \\
\hline Primulaceae & Anagallis monelli L., Anagallis arvensis L. & 2 & 1.94 \\
\hline Ranunculaceae & Ranunculus arvensis L., Anemone coronoria L., Anemone sp. & 4 & 3.88 \\
\hline Resedaceae & Reseda alba L. & 1 & 0.97 \\
\hline Rosaceae & Sanguisorba minor Scop, Rosa canina L., Rosa sempervirens L. & 3 & 2.91 \\
\hline Rubiaceae & Galium aparine L., Asperula hirsute & 2 & 1.94 \\
\hline Rutaceae & Ruta chalepensis ssp., Ruta montana (Clus.) L. & 2 & 1.94 \\
\hline Scorphulariaceae & Verbascum sinuatum L. & 1 & 0.97 \\
\hline Thymelaceae & Daphne gnidium L. & 1 & 0.97 \\
\hline Total & & 103 & $100 \%$ \\
\hline
\end{tabular}




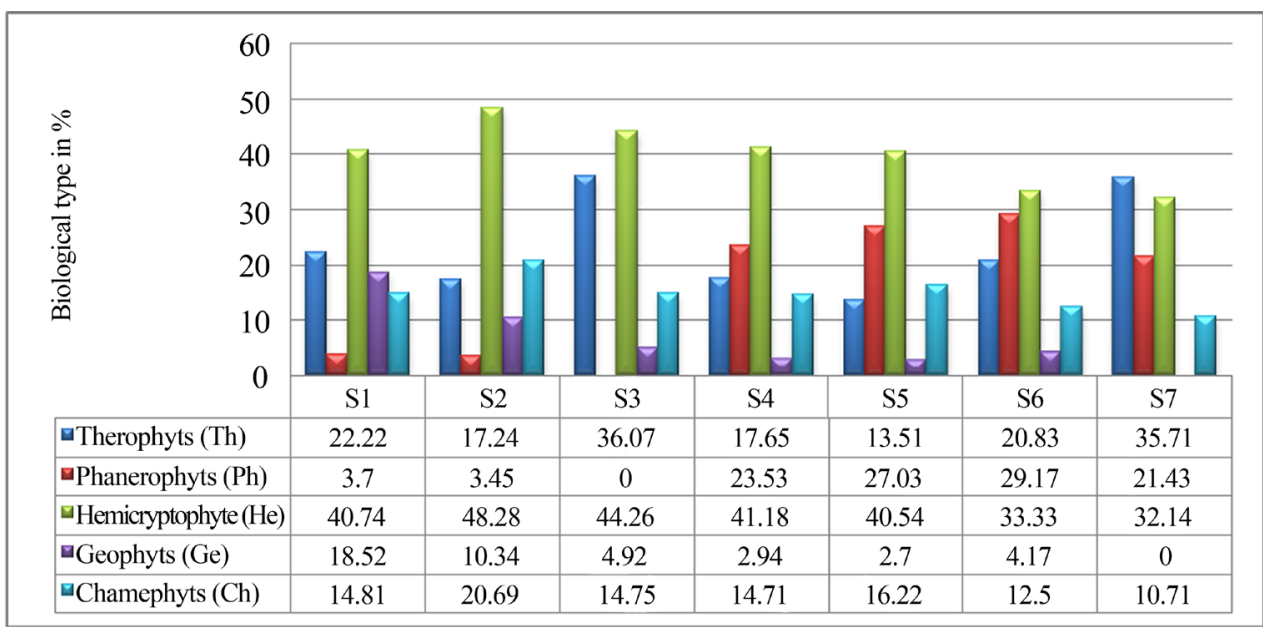

Figure 1. Biological spectrum of the species inventoried by sation.

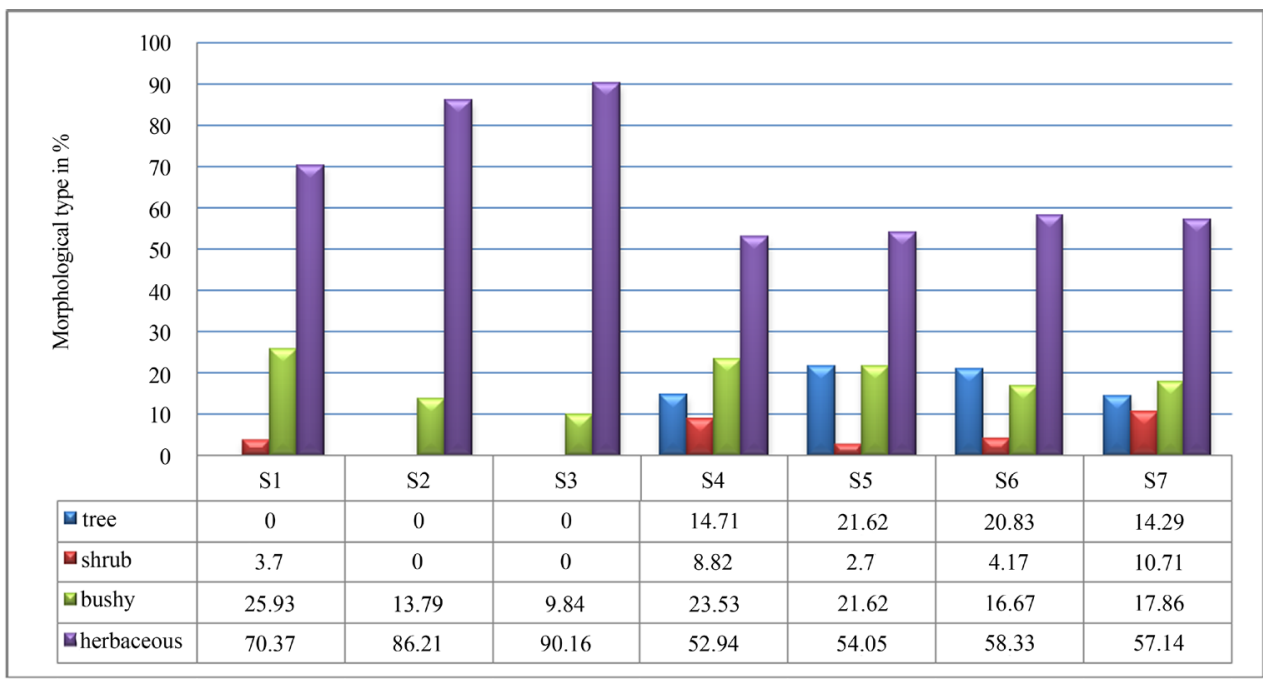

Figure 2. Morphological spectrum of species inventoried by station.

reflecting the low species distribution are inventoried. This is not the case in S2 and S3 stations where this index is low (between 0.03 and 0.07 ), reflecting a good distribution of listed species.

\subsection{Soil Analysis}

Table 3 is shown in the average values for the different physico-chemical characteristics of the surface soil horizon corresponding to the seven stations selected.

The ground station 3, 6 and 7 has a balanced texture and crumb structure; against by, one of the stations 1, 2, 4 and 5 is characterized by a sandy texture and a particulate structure. The humidity level is between 9.58 and $20 \%, \mathrm{pH}$ and conductivity indicate slightly alkaline soil and unsalted. Indeed, the $\mathrm{pH}$ is between 7.39 and 7.75 and the conductivity between 0.28 to $0.42 \mathrm{~ms} / \mathrm{cm}$.

The level of organic matter in the soil varies from one station to another. Stations 5 and 7 are moderately rich in organic matter (2.76\% and 3.74\%), while stations 1, 2, 3, 4 and 6 are filled with low rates of respectively $0.86 \%, 0.06 \%, 0.12 \%, 0.13 \%$ and $0.80 \%$.

Rates of total and active limestone present in the soil samples are very heterogeneous. According to standards established by Baize (1988), we note the presence of non-calcareous soils ( $<1 \%)$ (stations 4 and 5), little lime (5\% - 25\%) (2 stations and 7), moderately calcareous (25\% - 50\%) (station 6) and excessively calcareous (50\% 80\%) (stations 1 and 3). 
Table 3. Results of physico-chemical analysis of soil sampled stations.

\begin{tabular}{cccccccc}
\hline & St 1 & St 2 & St 3 & St 4 & St 5 & St 6 & St 7 \\
\hline Fgr (\%) & 11.82 & 8.61 & 9.94 & 7.43 & 12.5 & 10.23 & 15.3 \\
Sgr (\%) & 16.65 & 18.34 & 13.82 & 15.53 & 38.25 & 16.16 & 15.79 \\
Sfi (\%) & 60.03 & 63.21 & 65.77 & 72.49 & 41.25 & 40 & 30 \\
Arg (\%) & 4.51 & 4.94 & 28.51 & 3.22 & 3.33 & 13.63 & 17 \\
Lim (\%) & 6.61 & 4.79 & 28.38 & 8.76 & 4.59 & 28.81 & 22.46 \\
Texture & Sandblaster & Sandblaster & Balanced & Sandblaster & Sandblaster & Balanced & Balanced \\
Structure & Particulate & Particulate & Lumpy & Particulate & Particulate & Lumpy & Lumpy \\
Mor (\%) & 0.86 & 0.06 & 0.12 & 0.13 & 3.74 & 0.80 & 2.76 \\
Caa (\%) & 7.25 & 10 & 11.87 & 0.30 & 0.75 & 7 & 7.13 \\
Cat (\%) & $\mathbf{8 5 . 7 2}$ & 17.14 & 87.72 & 4.28 & 2.14 & 51.41 & 7.72 \\
Hum (\%) & 9.75 & 12.79 & 10 & 10.12 & 9.58 & 20 & 13.75 \\
Ph & 7.72 & 7.75 & 7.62 & 7.52 & 7.39 & 7.87 & 7.47 \\
Con (ms/cm) & 0.39 & 0.30 & 0.28 & 0.42 & 0.31 & 0.29 & 0.35 \\
\hline
\end{tabular}

Fgr: coarse fraction; Sgr: coarse sand; Sfi: fine sands; Arg: clays; Lim: silt; Mor: organic matter; Caa: active lime; Cat: total limestone, Hum: humidity; Con: electrical conductivity.

\section{Data Processing}

AFC executed whose matrix is the intersection of all the variables, soil and biological seven stations sampled, identifies three groups. The factorial design, the F1 axis that brings the most important statistical information in the AFC (57.67\% of inertia) compared to the axis F2 (21.53\%), opposed to the group 1 to group 2 and group 3 (Figure 3). Indeed, the choice of these three groups was made on the basis of the hierarchical cluster analysis (HCA) performed in parallel to determine the ecological characteristics of the seven study sites.

Based on the contributions that individuals make (stations) and variables (soil and biological parameters):

- Gr Group 1 is represented by St stations 4, St 5, St 6 and 7 where phanerophytes (Ph) dominate. This biological type against the factorial axes is seen attached to the particular highest altitude (Alt) and the best recovery rate of vegetation $(\mathrm{Rec})$, soil moisture $(\mathrm{Hu})$ and organic matter (Mor).

- The group Gr 2 is represented by the most degraded sites, St 1 and St 3, where therophyts (Th) dominate. This type is correlated with organic clays, high active and total rate of limestone and a high specific diversity.

- Gr 3 group is represented by two St station, also considered degraded and clearly dominate the chamaephyts (Ch), hemicryptophyts (He) and geophyts (Ge). These life forms are related mainly to coarse sand and purposes, the electrical conductivity of soil and slope.

\section{Discussion}

The 103 recorded species are divided into 39 taxonomic families and five biological types with predominance of hemicryptophytes (34.95\%), followed by therophyts (33.98\%). This reflects a deterioration whose origin is certainly anthropozoogène effect exerted by the man and his flock [7] [18].

Moreover, the rophytisation is characteristic of arid areas [19] [20]. According [21], the thérophytie is an adaptation against adverse conditions and a form of resistance to harsh climate strategy.

In third place is the place chamaephytes (12.62\%), followed by phanerophytes (10.68\%). This chaméphytisation originates from the phenomenon of desiccation [22]-[24]. Danin \& Orshan (1990) emphasize that chaméhytes adapt better to summer drought and strong light illumination, which explains their dominance in degraded stations. Grazing also promotes the chamaephytes comprehensively rejected by the herds [25].

Phanerophytes particularly prevalent in degraded shrubland and woodland to the corresponding stations St 4 St 5 St 6 and St 7. The general pattern of biological spectrum in all the stations is: $\mathrm{He}>\mathrm{Th}>\mathrm{Ch}>\mathrm{Ph}>\mathrm{Ge}$.

Analysis of the morphological spectrum of species inventoried shows the predominance of herbaceous plants (87 species, or $84.46 \%$ ) on wood (16 species, or $15.50 \%$ ). From these, the most important are bushy (8 species 


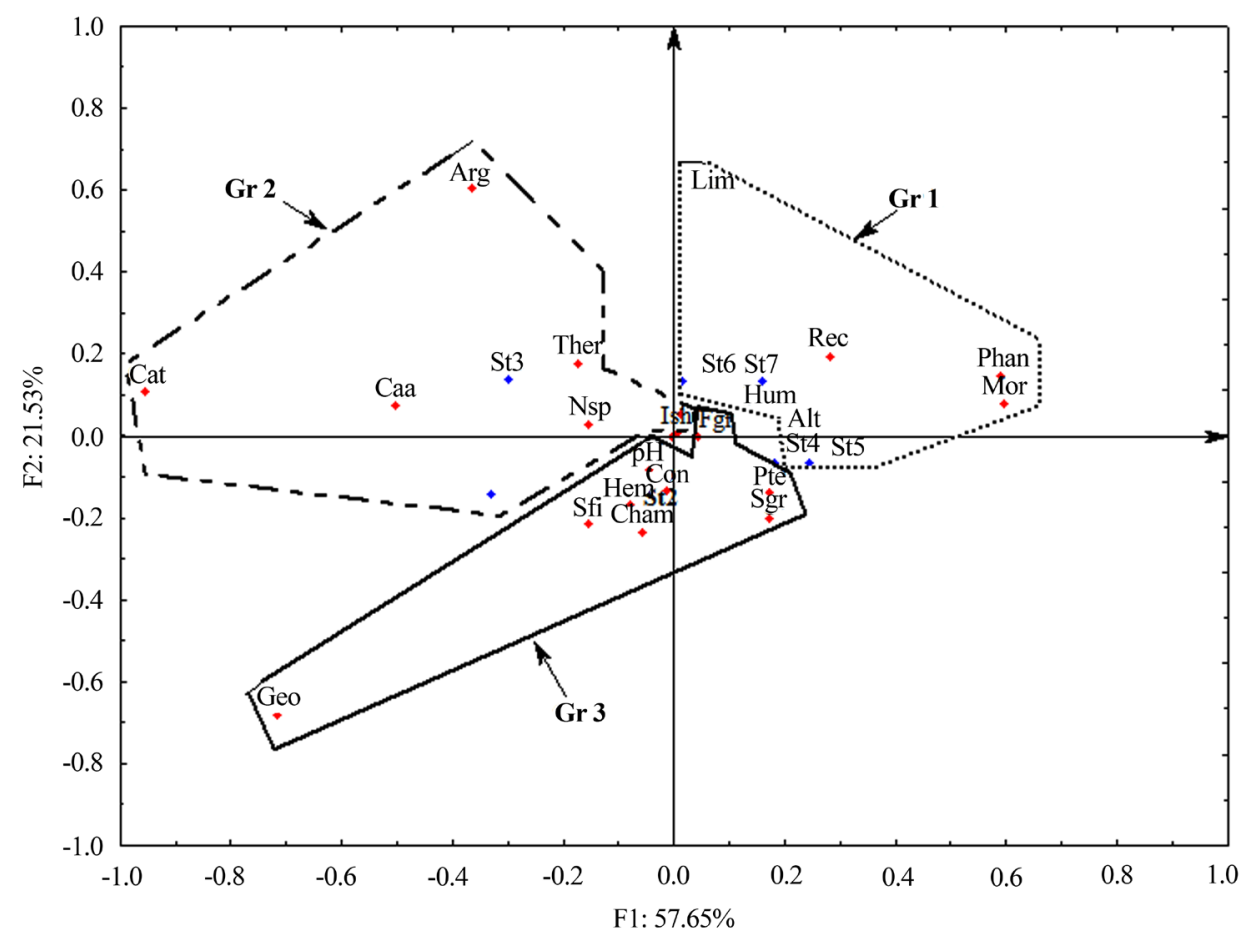

Figure 3. Graphical representation of the factorial correspondence analysis. Thér: therophyts; Phan: phanerophyts; Hem: hemicryptophyts; Cham: chamephyts; Géo: géophyts. Fgr: coarse fraction; Sgr: coarse sand; Sfi: fine sands; Arg: clays; Lim: silt; Mor: organic matter; Caa: active lime; Cat: total limestone; Hum: humidity; Con: electrical conductivity; Rec: recovery; Alt: Altitude; Pte: Slope; Nsp: number species; St: Station.

or $7.76 \%$ ), followed by tree (5 species, or $4.85 \%$ ) and shrublands (3 species or $2.92 \%$ ). Among the herbaceous annual predominate (47 species or $45.63 \%$ ) on perennial (40 species, or $38.83 \%$ ).

Biogeographically, almost all the species sampled stations belong to the Mediterranean element (35.92\%), the Eurasian element in second place with a rate of $6.79 \%$, and other elements are less represented. According to Quézel et al. (1992), the existence of various biogenic and biogeographic sets is a key factor in explaining species richness in the Mediterranean region.

Diversity indices of Shannon evaluated on seven different stations with variation between 1.09 and 1.95 bits/ individual values of each other (Table 4). This variation is related to the number of species. Therefore a high index of Shannon corresponds to favorable environmental conditions for the installation of many species represented by a small number of individuals. The index calculation evenness shows relatively large values for the stations

St 1 (0.13), St 4 (0.17), 5 St (0.14), 6 St (0.22) and St 7 (0.20) are low resulting a low distribution of species and, contrary the St $2(0.03)$ and St $3(0.07)$ where the fairness is low there explaining a good species distribution stations. These variations in the index of fairness are related mainly to the multiple pressures by man and grazing [26].

The physico-chemical analyzes carried out on our soil samples collected from the surface horizon, helped to highlight some peculiarities. Indeed, the composition of the horizon plays an important role on the behavior of vegetation [27] and most of the descriptors of soil mainly concern the surface horizon [14].

The physico-chemical soil parameters vary from one station to another. The floor has a crumbly texture and a balanced structure at stations 3, 6 and 7; sand and particulate at stations 1, 2, 4 and 5. Soil moisture fluctuates from one station to another. This fluctuation is related to the nature of the soil, its richness in organic matter, time and location of sampling [28].

Soil $\mathrm{pH}$ of all stations is slightly alkaline. This alkalinity can be related to the total amount of limestone in the soil [29]. According [30], the $\mathrm{pH}$ is not a stable characteristic of the soil, but different cations absorbed depends on the nature of the vegetation and climatic conditions. 
Table 4. Species diversity of the sampled stations.

\begin{tabular}{rccccccc}
\hline & St 1 & St 2 & St 3 & St 4 & St 5 & St 6 & St 7 \\
\hline Number of species & $\mathbf{2 7}$ & $\mathbf{2 9}$ & $\mathbf{6 1}$ & $\mathbf{3 4}$ & $\mathbf{3 7}$ & $\mathbf{2 4}$ & $\mathbf{2 8}$ \\
ISh (bit/individual) & $\mathbf{1 . 0 9}$ & $\mathbf{1 . 5 6}$ & $\mathbf{1 . 9 5}$ & $\mathbf{1 . 7 0}$ & $\mathbf{1 . 5 8}$ & $\mathbf{1 . 5 5}$ & $\mathbf{1 . 6 8}$ \\
Equitability (E) & $\mathbf{0 . 1 3}$ & $\mathbf{0 . 0 7}$ & $\mathbf{0 . 0 3}$ & $\mathbf{0 . 1 7}$ & $\mathbf{0 . 1 4}$ & $\mathbf{0 . 2 2}$ & $\mathbf{0 . 2 0}$ \\
\hline
\end{tabular}

Ish: Shannon diversity index.

The projection values of electrical conductivity on the international scale for measuring soil salinity indicates non saline soils for all stations.

The rate of organic matter in the soil of our study area varies from one station to another, medium in stations 5 and 7, low in stations 1, 2, 3, 4 and 6. This variability is related with the diversity and richness of vegetation, climate and nature of the substrate.

The low organic matter noted in stations 1, 2, 3, 4 and 6 are certainly due to the sandy nature of the substrate, not allowing the retention of organic matter [31].

Rates of total and active limestone present in the soil samples are very heterogeneous. Accordance with standards established by [32], we note the presence of non-calcareous soils (<1\%) (St 4 and 5), little lime (5\% - 25\%) (St 2 and St 7), moderately calcareous (25\% to 50\%) (St 6) and excessively limestone (50\% - 80\%) (St 1 and St 3).

Limestone character of our soil samples can be explained by the nature of the rock which is often limestone, promoting the installation of scrubland resulting from degradation of forest formations [33].

The synthesis of all these plant and soil data and their statistical treatment by the AFC and the CHA has enabled us to provide additional information on their interpretation.

The projection of plant life forms characterizing all explored stations and soil parameters evaluated on their soil in the plane F1/F2 AFC, taking into account their contributions points to three major groups (Gr 1, Gr 2 and Gr 3)

- The Gr1 group is represented by the St 4 and 7 stations, St 5, St 6 where phanerophyts dominate. This biological type against the factorial axes is seen attached including recovery rate (Rec: 0.899), altitude (Alt: 0.910) in soil moisture (Hum: 0.522), the stringers (L: 0.953) and organic matter (Mor: 0.770); it is mainly related to the following species: Ampelodesma mauritanica (Poiret) Dur. and Sch; Bellis Anua L; Bromus rubens L., Calycotome intermedia (Salzm) c.presl; Campanula sp.; Ceratonia siliqua L.; Chamaerops L.; Crataegus monogyna L.; Cupressus sempervirens L.; Cynoglossum creticum Miller; Dactylis glomerata L.; Elaeoselinum sp; Erythraea sp; Eucalyptus globulus L.; Foeniculum vulgare L.; Fraxinus excelsior L.; Galium aparine L.; Hedera helix; Helianthemum apperinum L.; Marrubium vulgare L.; Olea europaea L.; Phyllareae angustifolia L.; Pinus halipensis L.; Pistascia atlantica Desf; Pistascia lentiscus L.; Quercus ilex L.; Raphanus raphanistrum L.; Rosa sempervirens L.; Ruta chalipensis; Ruta montana L.; Salvia argentea L.; Silybum marianum L.; Sisymbrium officinale L.; Sisymbrium officinale L.; Sonchus tenerrimus L.; Stipa tenacissima L.; Teucium polium L.; Trifolium angustifolium L.

This group of species characterize the least degraded sites where essentially dominated by descending phanerophyts, hemicryptophyts, therophyts the champhyts and geophyts. This relationship between these biological types and altitude is confirmed by the AFC. The effect of altitudinal gradient considered in this study on the distribution of life forms is certainly correlated with the variability of certain local climatic parameters, especially rainfall, temperature and humidity. These parameters fluctuate with altitude and have a direct effect on the behavior of vegetation. In this context, the work of [34] highlight the effect of altitudinal variation on the phenological behavior asphodelus microcarpus Salzm. and Viv, moving in the same site where the present work is carried out.

- Gr 2 group is represented by highly degraded sites (St 1 and St 3 ) where therophytes dominate. This type is correlated with organic clays (Arg: 0.914), a significant level of active limestone (Caa: 0.708) and total (Cat: 0.513).

The species found in this group are: Ajuga iva L.; Ammi Visnaga L. Lamk; Anagallis arvensis L.; Lysimachia monelli L.; Perfoliata Blackstonia L.; Brassica alba L.; Calendula arvensis L.; Bryonia dioica Jasq; Carduus pycnophalus L.; Centaurea acaulis L.; Centaurea eriophora L.; Centaurea pullata L.; Chamaerops L.; Plas- 
tered subsp; Dactylis glomerata L.; Daphne gnidium L.; Daucus carota L.; Dactylis glomerata L.; Erodium moschatum (Burm.) Eruca visicaria L.; Erythraea sp; Hordeum maritimum witth; Lagurus ovatus L.; Linum sp; Malva sylvestris L.; Linum sp; Lobularia maritima (L.) Desv; Malva sylvestris L.; Onobrychis argentea Boiss; Ornithogalum umbellatum L.; Papaver hybridum L.; Pallenis spinosa L.; Papaver rhoeas L.; [24] reported that a system is more influenced by man (grazing, culture) and more therophytes hémycriptophytes gaining importance. In our case and in this group, the most important biological type is represented by therophytes, reflecting strong anthropogenic pressure.

- Gr 3 group is represented by the St station where two clearly dominate the chamaephyts, hemicryptophyts and geophyts. These types are related to biological coarse sand (Sgr: 0.425) for sand (Sfi: -0 , 759), the coarse fraction (Fgr: 0.542), pH (-0.566), electrical conductivity (Con: -0.496$)$ and the slope (Pte: 0.559). The high rate of that station in chamaephyts gradient reflects the state of the latter.

The chamaephyts and geophyts in the shrubland and scrubland are better adapted to aridity. For [35], the chamaephyts are better suited than phanerophyts drought. This group is from the further degradation of Mediterranean formations favoring the installation of scrubland where species grow on limestone substrate [36].

\section{Conclusions}

The forest ecosystem of Mount Tessala is among the largest and most diverse ecosystems in western Algeria. However, the combined action of the anthropozoogène pressure and weather conditions greatly affects flora.

Our job is to identify and analyze plant diversity along an altitudinal gradient in the southern slope of mount rise. For this purpose, we select seven stations inside which phytoecological surveys are conducted.

The species inventoried and having been kept in a herbarium with the number of 103, distributed over 39 botanical families dominated by Asteraceae (14.56\%), Poaceae and Lamiaceae (7.77\%) and Brassicacea (6.80\%).

The study of biological types reveals the dominance of hemicryptophyts (34.95\%) and therophyts (33.98\%), followed by chamaephyts (12.62\%), the phanerophyts $(10.68 \%)$ and geophyts $(7.77 \%)$. This biological spectrum is a typical spectrum of the semi-arid bioclimatic characteristic of vegetation subjected to drought and human action.

Morphologically, the vegetation of our study area is distinguished by herbaceous formations, bushy, shrub and tree. These vegetation types are also the result of several factors such as the intervention of the man and his flock, and climate change exerting some influence on the distribution of different classes of morphological types.

From the biogeographic point of view, the Mediterranean element is predominant. The other elements are poorly represented, their presence can be seen as an index of change in climatic conditions in the region.

The processing of data obtained by correspondence analysis (AFC) and the hierarchical cluster (HCA) reveals the existence of three groups of stations that differ from their species diversity and their state of degradation. Indeed, Gr 2 and Gr 3 with degraded stations at low altitude (St 1, St 2, St 3) groups are correlated with hemicryptophyts and therophyts; while the Gr 1 group represented by the least degraded stations (St 4, St 5, St 6 and St 7) located in high altitudes, has an affinity with phanerophyts that are linked to favorable soil conditions.

As part of our future work, we plan to complete this floristic inventory in increasing our sampling and analyzing the more phytodiversity Mount Tessala, exploring both the north and south slopes. This will elucidate the organization, development and functioning of this ecosystem whose ecological interest is considerable.

\section{References}

[1] Quézel, P. and Barbero, M. (1989) Formations Creeping Juniper Djurjura. Their Ecological Significance, Dynamic and Syntaxonomique in a Comprehensive Approach to Kabyle Cedar Forests. Lazaroa II: 85-99.

[2] Medail Quézel F.P. (2003) Possible Ecological Consequences of Climate Change on the Flora and Vegetation of the Mediterranean Basin. Bocconea, 16, 000-000.

[3] Hasnaoui, O. (1998) Study Groups to Chamaerops L. Var. Argentea in the Tlemcen Region. Magister Thesis, University of Tlemcen, Algeria, $176 \mathrm{p}$.

[4] Bouzidi, M.A., Latreche, A., Attaoui, I., Mehdadi, Z. and M. Benyahia (2009) Characterization of Matorral and Scrubland to Urginea Pancration Phil. in Jebel Tessala (Western Algeria). Physical Geography and environment, 3, 131-149.

[5] Bouzidi, M.A., Latreche, A., Attaoui, I., Benabderrahmane, M., Mehdadi, Z. and M. Benyahia (2012) Antibacterial Effect of the Essential Oils Extracted from Ruta chalepensis L. and Ruta montana (L.) L. Journal of Life Sciences, 6 , 
898-902.

[6] Bouterfas, K., Mehdadi, Z., Latreche, A. and Cherifi, K. (2013) Autoecology White Horehound (Marrubium vulgare L.) and Characterization of Plant Biodiversity in Jebel Tessala (Northwestern Algeria). Ecologia Mediterranea, 39, 39-57.

[7] Cherifi, K., Mehdadi, Z., Latreche, A. and Bashir Bouiadjara, S.E. (2011) Impact of Anthropozoogène Action on the Forest Ecosystem of Mount Tessala (Western Algeria). Drought, 22, 197-206.

[8] Kiekken, R. (1962) Geology and Stratigraphy of Mountains Tessala. Floquet, Oran, 220 p.

[9] Benyahia, M., Benabdeli, K. and Moueddene, K. (2001) Geology, Soil and Production Systems in the Mountains of Tessala (Sidi Bel Abbes). Journal of Science of Nature and Environment (Ecosystems), 1, 70-75.

[10] Braun-Blanquet, J. (1952) Phytosociology Applied. International Station Communication Geobotany Mediterranean and Alpine, Montpelier, 156-161.

[11] Quézel, P. and Santa, S. (1962) New Flora of Algeria and Desert Regions Méridionales. Vol. I, CNRS, Paris, 565 p.

[12] Grall, J. and Hily, C. (2003) Treatment Situational Data (Fauna). FT-10-2003-01.doc.

[13] Daget, P. (1977) The Mediterranean Bioclimate. General Characteristics Representation. Vegetation, 34, 1-20. http://dx.doi.org/10.1007/BF00119883

[14] Devineau, J.L. (2001) Indicator Land Woody Species in Savannahs and Fallows Western Burkina Faso. Phytocoenologia, 31, 325-351.

[15] Lebart, L., Morineau, A. and Piron, M. (1997) Statistics Exploratory Multidimensional. Dunod, Paris, 439 p.

[16] Benzecri, J.-P. (1984) Information of the Data Analysis. Analysis and Classification of Connections. Dunod, Paris, 456 p.

[17] Masharabu, T., Noret, N., Lejoly, J., Bigendako, J. and Bogaert, J. (2010) Comparative Study of Floristic Parameters Ruvubu National Park, Burundi. Geo-Eco-Trop, 34, 29-44.

[18] Letreuch-Belarouci, A., Medjahdi, B., Letreuch-Belarouci, N. and Benabdeli, K. (2009) Benabdeli Floristic Diversity of the Cork Forests Tlemcen National Park (Algeria). Acta Botanica Malacitana, 34, 77-89.

[19] Daget, P. (1980) Of the Biological Types as Adaptive Strategy (Case of Therophytes). In: Barbault, R., Blandin, P. and Meyer, J.A., Eds., Searching Theoretical Ecology, Adaptive Strategies, Maloine, Paris, 89-114.

[20] Barbero, M., Loisiel, R. and Quézel, P. (1990) The Contributions of Phyto-Ecology in the Interpretation of Changes and Human-Induced Disturbances on Mediterranean Forest Ecosystems. Mediterranean Forests, 2, 194-215.

[21] Daget, P. (1982) Species Ecology Analysis in Communities. Ecology Collection 18, Editions Masson, Paris, 163 p.

[22] Raunkiaer, C. (1934) The Life Forms of Plants and Statistical Plant. Claredon Edition Press, Oxford, 632 p.

[23] Orshan, G., Montenegro, G., Avila, G., Aljaro, M.E., Walckowiak, A. and Mujica, A.M. (1984) Plant Growth Forms of Chilean Scrub. A Monocharacter Growth Form Analysis Along Altitudinal Transect Year from Sea Level to $2000 \mathrm{~m}$ asl. Bulletin de la Société Botanique de France, 131, 411-425.

[24] Floret, C., Galan, J., Le Floch, E., Orshan, G. and Romane, F. (1990) Growth Forms and Phenomorphology Year Traits along Environmental Gradient: Tools for Studying Vegetation. Journal of Vegetation Science, 1, 71-80. http://dx.doi.org/10.2307/3236055

[25] Kadi-Hanifi, H. and Achour, H. (1998) Alfa in Algeria Syntaxonomie, Relationship Middle Vegetation Dynamics and Future Prospects. PhD Thesis, USTHB, Algiers, 270 p.

[26] Benabadji, N. and Bouazza, M. (2001) The Impact of Man on the Forest in the Tlemcen. Mediterranean Region, XXII, 269-274.

[27] Aubert, G. (1978) Methods of Soil Analysis. 2nd Edition, CNDP, Marseille, 199 p.

[28] Aubert, G. (2003) Biodiversity and Ecological Processes at the Interface Soil-Vegetation in Beech Forests on High Silt Normandy. PhD Thesis, University of Rouen, Rouen, 59 p.

[29] Sari, A. (2004) Study of Soil-Vegetation Relationships of Some Halophytes in the Northern Region of Remchi. Magister Thesis, University of Tlemcen, Tlemcen, $199 \mathrm{p}$.

[30] Dajoz, R. (1982) Accurate Ecology. Gauthier Villars, 503 p.

[31] Amrani, M. (1989) Contribution to the Study of the Development of Steppe Areas Elgor (Tlemcen Region). Magister Thesis, University of Tlemcen, Tlemcen, 138 p.

[32] Baize, D. (1988) Guide Routine Analysis in Soil Science: Choice, Expression, Presentation and Interpretation. INRA, Paris, $172 \mathrm{p}$.

[33] Benabdeli, K. (1983) Development of a Methodology for Assessing the Anthropozoogène Action on the Vegetation of the Telagh Region (Algeria). PhD Thesis, University of Aix-Marseille, 183 p.

[34] El bouhissi, M. (2011) Study Asphodelus microcarpus Salzm \& Viv. Mount Tessala (Western Algeria): Histology, 
Autoecology and Assay of Cell Wall Polysaccharides. Magister Thesis, University Djillali Liabes, Sidi Bel Abbes, 96 p.

[35] Benabadji, N. and Bouazza, N. (2001) The Impact of Man on the Forest in the Tlemcen Region. Mediterranean Forests, 22, 269-274.

[36] Bouazza, M., Benabadji, N. and Loisel, R. (2001) Balance Sheet of the Flora of the Region of Tlemcen (Oran-Algeria). Mediterranean Forests, XXII, 130-136. 